\title{
DYNAMICS OF VOLATILITY SPILLOVER BETWEEN STOCK AND FOREIGN EXCHANGE MARKET: EMPIRICAL EVIDENCE FROM CENTRAL AND EASTERN EUROPEAN COUNTRIES
}

Ngo Thai Hung

\begin{abstract}
We use an Exponential Generalised Autoregressive Conditional Heteroskedasticity (EGARCH) model to investigate the asymmetric volatility spillover effects between the stock market and foreign exchange market in Hungary, Poland, the Czech Republic, Romania and Croatia for the pre- and post- financial crisis periods. The whole of the study period covers from $1^{\text {st }}$ April 2000 to $29^{\text {th }}$ September 2017. The results reveal bidirectional volatility spillover between stock and foreign exchange market of Hungary in all periods and Poland in the post-crisis period, unidirectional volatility spillover in Croatia in the pre-crisis period and from the stock market to exchange market in the Czech Republic during two periods. In the post-crisis period, the two financial markets show the non-presence of the volatility spillover between them in Croatia. Furthermore, empirical results from our analysis provide valuable insights to investors, multinational companies and economic policy makers regarding financial decision making.
\end{abstract}

JEL codes: $\mathrm{C}_{15} ; \mathrm{F}_{31} ; \mathrm{G}_{15}$

Keywords: volatility spillover, Central and Eastern European Countries, ARCH, GARCH, EGARCH, exchange rate, stock market

\section{INTRODUCTION}

The interlinkage between the stock and foreign exchange markets has attracted the attention from academic researchers and practitioners alike for a long time and offers meaningful insight into them. It is widely acknowledged that rapid growth in international financial markets has become substantially more integrated in recent years. The drastic increasing trend in financial assets has been followed by

1 Ngo Thai Hung: Corvinus University of Budapest, Department of Finance, PhD student. 
increasing in high demand and supply of foreign currencies. The interdependency has been generated by both the high demand of currencies and equity flows, leading to some degree of interdependency in both securities and currencies. According to Kanas (2000), the huge increases in interdependency has also increased the volatility spillovers between stock and foreign exchange markets, positive and significant spillovers of volatility transmission may increase the nonsystematic residual international portfolio risk faced by global investors, this might reduce the gains from international portfolio diversification. In reality, volatility analysis helps us to understand the information mechanism in both financial markets including price and volatility spillovers across markets, shock propagation across foreign exchange and stock markets and hedging strategy problems (Aloui, 2007). In recent finance literature, there is a lot of interest in the financial press on the relationship between returns in the stock and foreign exchange markets because the financial roles of both variables play in prominent portfolio decisions and economic development. Theory suggests two broad channels which link return in stock and exchange markets. The first approach known as the flow-oriented models of exchange rates Dornbusch-Fischer (1980), this approach posits that there exists a positive linkage between exchange rates and stock prices, and specifically centering on the current account and trade balance. The second approach known as the stock-oriented models of exchange rates (Frankel, 1983), these models suggest that the exchange rate is determined by the demand and supply of financial assets such as equities and bonds. More recently, the information of volatility spillovers between the two financial markets has been studied by many researchers for different countries. However, this paper distinguished itself from the previous studies in the following ground. A lot of studies exist in the developed and emerging markets, but for developing markets such as Hungary, Poland, Czech Republic, Romania and Croatia, there are only two investigations of Morales (2008) and Fedorova-Saleem (2010) regarding volatility spillover effect between stock and foreign exchange markets. Morales (2008) undertook his study on preand post-europe periods in Hungary, Poland, Czech Republic and Slovakia, while Fedorova-Saleem (2010) focused on the questions of volatility spillover effects of Poland, Hungary, Russia, and the Czech Republic. However, in this research, we studied in the Hungarian, Polish, the Czech Republic, Romanian and Croatian financial markets on subprime financial crisis period, and the methodology adopted is not the same with that of our purposed study.

In this paper, we employ the EGARCH model to address some critical research questions. First, the persistence and asymmetric effects in the conditional volatility of daily returns on stock and exchange indices in Central and Eastern European countries in the pre-and post-crisis periods. Second, whether there is a relationship between the two financial markets or not in these countries. Besides, 
making comparisons between different countries and various time periods has been performed.

The organization of the paper is as follow. The next section (Section 2) gives the relevant literature review. Section 3 discusses the EGARCH model. Section 4 presents and discusses the estimation results of EGARCH model. Section 5 summarizes the study and concludes with some implications.

\section{LITERATURE REVIEW}

There is a rich empirical literature which exists on the investigation of the volatility transmission mechanism of the dynamic linkage between the exchange rates and the stock market. We must mention to the theoretical framework of Diebold - Yilmaz (2009; 2012; 2014), Generalized VAR have shed light on the connectedness of stock returns as well as volatility index. Nevertheless, the asymmetric has not been mentioned in these studies. Under our research, we applied popular econometrics GARCH family to capture the information mechanism of volatility spillovers.

Many of these studies are based on the Generalized ARCH(GARCH) framework to examine volatility spillovers between two financial markets in different countries. It is clear that in the context of the literature of the volatility spillover can be divided into three key points: first, a bidirectional volatility spillover between two markets; second, an unidirectional flow of volatility from stock market to exchange market and vice versa; third, non-persistence of the volatility spillover between two financial markets.

The first study of analyzing volatility spillovers was conducted by (Kanas, 2000), he used daily data for the period from January $1^{\text {st }}, 1986$ to February $28^{\text {th }}, 1998$ and investigated six industrialised countries, namely the US, the UK, Japan, Germany, France and Canada by employing the bivariate EGARCH model for conditional variances. He found evidence of spillovers from stock returns to exchange rate returns for all countries except Germany, the non-persistence of spillovers from exchange to the stock market.

Yang-Doong (2004) applied the bivariate EGARCH model on weekly data from May $1^{\text {st }}, 1979$ to January $1^{\text {st }}, 1999$ to examine the nature of the mean and volatility spillover between stock and foreign exchange markets for the G-7 countries. Their empirical evidence supports the asymmetric volatility spillover effect from the stock market to the foreign exchange market in France, Italy, Japan and the US.

Aloui (2007) explored the nature of the mean, volatility and causality transmission mechanism between stock and foreign exchange markets for the US and some 
major European markets (France, Germany, Belgium, Spain, Italy). The dataset consisted of daily closing exchange rates and stock indexes for these countries. The asymmetric volatility transmission was illustrated by EGARCH model. He found the asymmetric and long-range persistence volatility spillover effect and evidence of causality in mean and variance in the two markets for both pre- and post-euro periods. Additionally, the author confirmed that the stock returns had a more significant effect on the foreign exchange rate for the two subsamples.

Volatility spillovers between stock returns and foreign exchange rates in four Central and Eastern European countries (Hungary, Czech Republic, Poland and Slovakia) was studied by Morales (2008). The author applied daily data for the 1999-2006 period that was divided into two sub-periods, pre-euro and post-euro. The analyses were carried out on EGARCH model in which apparently confirmed that there was non-existence of significant volatility spillover from stock to foreign exchange markets in these countries. However, the overall results were the lack of significant spillovers from exchange rates to stock returns and volatility in both markets tended to decrease after the countries joined the European Union.

Fedorova-Saleem (2010) investigated the dynamic volatility spillover between stock and currency markets in emerging Central and Eastern European markets of Poland, Hungary, Russia, and the Czech Republic. By estimating a bivariate GARCH-BEKK model using weekly returns. The findings showed strong evidence of direct linkages between the equity markets in term of both returns and volatility and currency markets. The unidirectional volatility spillovers from currency to stock markets had been highlighted for all countries except the Czech Republic in this research.

Valls-Chuliá (2014) used a multivariate asymmetric GARCH model to examine volatility spillovers between stock and currency markets in Asian economies, consisted of 2893 observations daily indices, in the period 2003 to 2014 . Their results presented evidence of bidirectional volatility spillovers between both markets, independently of the individual country's level of development.

Mozumder et al. (2015) examines the volatility spillover between stock prices and exchange rates in three developed and three emerging countries including Ireland, Netherlands, Spain, Brazil, South Africa and Turkey, across the recent prefinancial-crisis, crisis and post-crisis periods, using weekly data and employing a bivariate EGARCH model. The study concluded that there are the asymmetric volatility spillover effects between both markets in both developed and emerging economies during the financial crisis. Namely, the findings indicated that there is a unidirectional volatility spillover effect running from stock returns to exchange rate returns in developed countries. Volatility spillover direction between the two markets is opposite in the emerging countries, but there is a bidirectional volatility spillover both financial markets in Brazil. At the same time, Segal-Shali- 
astovich-Yaron (2015) suggested an empirical methodologies for studying good and bad aggregate uncertainty in terms of defining bad and good uncertainty as the variance portion of an aggregate variable. The findings put forward that good certainty is associated by subsequent positive growth of aggregate measures consumption, while bad uncertainty is followed by a decline in this growth rate. Additionally, based on the theoretical framework, the results reported that asset prices rise with good uncertainty while they decline with bad uncertainty. It means that their research question of macroeconomic uncertainty increase or decrease aggregate growth and asset prices has been clear.

Dynamics of volatility spillover between the stock market and foreign exchange market in Asian countries (China, Hong Kong, India, Japan, Pakistan and Sri Lanka) was empirically investigated by (Jebran and Iqbal 2016) by using EGARCH model. This study considered daily data from January $4^{\text {th }}, 1999$ to January $1^{\text {st }}, 2014$. Their research pointed out bidirectional asymmetric volatility spillover between the stock market and foreign exchange market of Pakistan, China, Hong Kong and Sri Lanka. For India, the findings shown unidirectional transmission of volatility from stock to exchange markets. Nevertheless, the analysis also confirmed no evidence of volatility spillover in both markets in case of Japan. At the same time, Baruník-Kočenda-Vácha (2016) utilized data covering most liquid U.S. stocks in seven sectors to examine how to quantify asymmetries in volatility spillovers that emerge because of bad and good volatility. The authors illustrated that the asymmetric connectedness of stocks at the disaggregate level as well as the spillovers of good and bad volatility were transmitted at various magnitudes. Also, the findings found that overall intra-market connectedness of U.S stocks increased substantially during the recent financial crisis.

It is clear from the above review of relevant literature that there are mixed results on volatility spillover effects from various periods as well as different countries. This study aims at contributing to the existing literature by filling the gap of exploring knowledge about the volatility transmission mechanism of the dynamic linkage between the exchange rates and the stock market in the selected countries by adopting an empirical approach based on a multivariate EGARCH model. Also from EGARCH model, examining the relationship between stock and exchange rate movements has been estimated, the questions of the previous researches have centered only on the first moments of the joint stock and exchange rate distributions. Another contribution of our study is considering daily data for the precrisis period of 9 years and the post-crisis period of 10 years to research in the long run because daily data capture more information than weekly and monthly data and so as to ascertain the extent to which the recent financial crisis affected the link in question. Furthermore, empirical results from our analysis are of great 
interest to investors, multinational companies and economic policymakers regarding financial decision making.

\section{METHODOLOGY}

\subsection{Data}

The data set consists of daily closing stock and exchange rate prices for five Central and Eastern European countries, we took daily data covering the period from $1^{\text {st }}$ April 2000 to $29^{\text {th }}$ September 2017. The entire investigation period is subdivided into two sub-periods: Pre-crisis period: $1^{\text {st }}$ April 2000 to $29^{\text {th }}$ August 2008. Postcrisis period: $1^{\text {st }}$ September 2008 to $29^{\text {th }}$ September 2017. The whole period in present study divides into pre and post financial crisis period on the basis of certain justifications. The reason for collecting daily data is to capture more the precise information content of changes in stock prices and exchange rates than doing with weekly or monthly data (Jebran and Iqbal 2016), and better able to capture the dynamics between variables (Agrawal et al. 2010). The sample five European countries includes Hungary, Poland, Czech Republic, Romania and Croatia and their stock indexes are: Budapest Stock Exchange BUX, Warsaw Stock Exchange WIG, Prague Stock Exchange PX, Bucharest Stock Exchange BET and Zagreb Stock Exchange respectively. The national currencies of these countries are Hungarian Forint HUF, Polish Zloty PLN, Czech Koruna CZK, Romanian Leu RON and Croatian Kuna HRK respectively. The exchange rate series are from the European countries are stated in US dollars per local currency (note that value of the dollar). Because stock markets operate for five trading days from Monday to Friday and foreign exchange markets operate six trading days (excluding weekends and holidays), this research makes a common data series by adjusting the dates of both the stock and exchange rate indices. The data for our empirical investigation is obtained from Bloomberg, accounted by the Department of Finance, Corvinus University of Budapest. The daily return data series are calculated as $R_{i, t}=100 \times$ $\ln \left(P_{i, t} / P_{i, t-1}\right)$, where $P_{i, t}$ is the price level of market $i(i=1$ for the stock market and $i$ $=2$ for the foreign exchange rate) at time $t$. The plots of stock prices and exchange rate series for five countries in sample illustrate the volatility that occurs in bursts. The raw series are plotted in Figure 1 where stock markets and foreign exchange rate markets in five countries fluctuate in the pre and post crisis periods. 
Table 1

Descriptive statistics of daily return of stock indices

\begin{tabular}{cccccc}
\hline Countries & Hungary & Poland & Czech & Romania & Croatia \\
\hline Mean (\%) & 0.04 & 0.03 & 0.05 & 0.11 & 0.07 \\
SD (\%) & 1.39 & 1.30 & 1.26 & 1.78 & 1.39 \\
Skewness & -0.0883 & -0.2559 & -0.1862 & -0.1390 & 0.5367 \\
Kurtosis & 4.3107 & 5.1726 & 5.4575 & 21.9218 & 16.726 \\
Jarque-Bera & $157.88^{* *}$ & $449.76^{* *}$ & $559.39^{* *}$ & $313320^{* *}$ & $16342.68^{* *}$ \\
PP test & $-44.47^{*}$ & $-44.92^{*}$ & $-44.96^{*}$ & $-43.33^{*}$ & $-44.93^{*}$ \\
ADF test & $-44.49^{*}$ & $-44.79^{*}$ & $-44.96^{*}$ & $-43.36^{*}$ & $-44.92^{*}$ \\
N & 2166 & 2166 & 2173 & 2099 & 2069 \\
& & Panel B. Post-crisis period & & \\
Mean (\%) & 0.02 & 0.02 & -0.01 & 0.01 & -0.02 \\
SD (\%) & 1.62 & 1.22 & 1.4927 & 1.52 & 1.18 \\
Skewness & -0.1033 & -0.5254 & -0.6210 & -0.7250 & 0.0734 \\
Kurtosis & 11.4429 & 7.9297 & 20.3306 & 15.5740 & 27.2175 \\
Jarque-Bera & $6746.18^{* *}$ & 2407.276 & $28642.34^{* *}$ & $15240^{* *}$ & 55425.20 \\
PP test & $-45.07^{*}$ & $-34.53^{*}$ & $-39.97^{*}$ & $-44.89^{*}$ & $-44.53^{*}$ \\
ADF test & $-35.42^{*}$ & $-42.73^{*}$ & $-44.53^{*}$ & $-44.93^{*}$ & $-25.32^{*}$ \\
N & 2270 & 2274 & 2277 & 2283 & 2268 \\
\hline
\end{tabular}

Note: $\mathrm{SD}$ - standard deviation. $\mathrm{N}$ - bservations.

Critical value at $1 \%, 5 \%$ and $10 \%$ are $-3.43,-2.86$ and -2.56 respectively. PP is Phillips Perron test. ADF is Augmented Dickey Fuller test. ${ }^{* *}$ denotes the level of significance at $5 \%$, ${ }^{*}$ indicates $p<1 \%$

Source: the calculation of the author. 
Table 2

Descriptive statistics of daily changes in exchange rate return

\begin{tabular}{cccccc}
\hline Countries & Hungary & Poland & Czech & Romania & Croatia \\
\hline Mean (\%) & -0.0196 & -0.026 & -0.033 & 0.0129 & -0.02 \\
SD (\%) & 0.78 & 0.6937 & 0.7049 & 0.6516 & 0.69 \\
Skewness & 0.4141 & 0.2921 & 0.0008 & 0.9338 & -0.0863 \\
Kurtosis & 6.1554 & 5.3131 & 4.2452 & 20.066 & 5.0085 \\
Jarque-Bera & $960.48^{* *}$ & $513.65^{* *}$ & $140.39^{* *}$ & $25778.4^{* *}$ & $350.36^{*}$ \\
PP test & $-46.89^{*}$ & $-43.80^{*}$ & $-47.20^{*}$ & $-48.94^{*}$ & $-50.02^{*}$ \\
ADF test & $-46.89^{*}$ & $-43.80^{*}$ & $-47.19^{*}$ & $-48.80^{*}$ & $-49.99^{*}$ \\
N & 2166 & 2166 & 2173 & 2099 & 2069 \\
& & Panel B. Post-crisis period & & \\
Mean (\%) & 0.02 & 0.02 & 0.01 & 0.02 & 0.01 \\
SD (\%) & 1.0559 & 1.04 & 0.85 & 0.77 & 0.69 \\
Skewness & 0.1971 & 0.2039 & -0.1349 & 0.2228 & -0.0347 \\
Kurtosis & 6.0054 & 6.6307 & 8.3099 & 6.6083 & 5.6903 \\
Jarque-Bera & $869.04^{* *}$ & $1264.76^{* *}$ & $2681.99^{* *}$ & $1257.42^{* *}$ & $684.43^{* *}$ \\
PP test & $-47.65^{*}$ & $-47.85^{*}$ & $-48.39^{*}$ & $-45.12^{*}$ & $-47.68^{*}$ \\
ADF test & $-47.61^{*}$ & $-47.71^{*}$ & $-48.38^{*}$ & $-34.59^{*}$ & $-47.68^{*}$ \\
N & 2270 & 2274 & 2277 & 2283 & 2268 \\
\hline
\end{tabular}

Note: SD - standard deviation. $\mathrm{N}$ - observations.

Critical value at $1 \%, 5 \%$ and $10 \%$ are $-3.43,-2.86$ and -2.56 respectively. $\mathrm{PP}$ is Phillips Perron test. ADF is Augmented Dickey Fuller test. ${ }^{*}$ denotes the level of significance at $5 \%,{ }^{*}$ indicates $p<1 \%$. Source: the calculation of the author. 
Figure 1

Plots of the indices for the sample pre- and post-crisis periods.
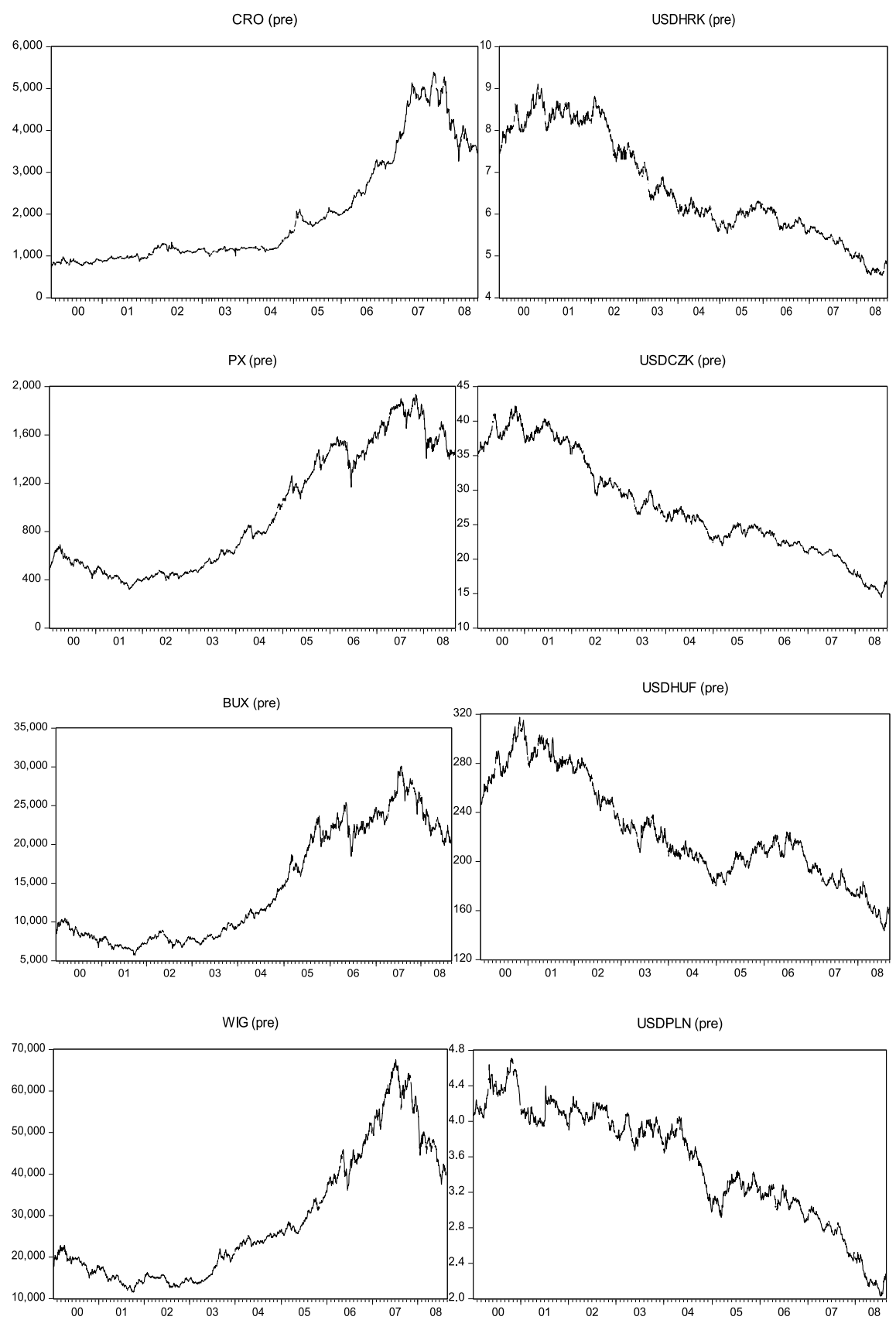


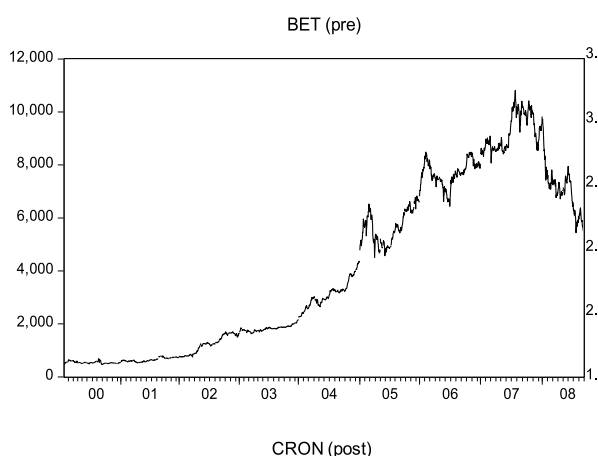

USDRON (pre)
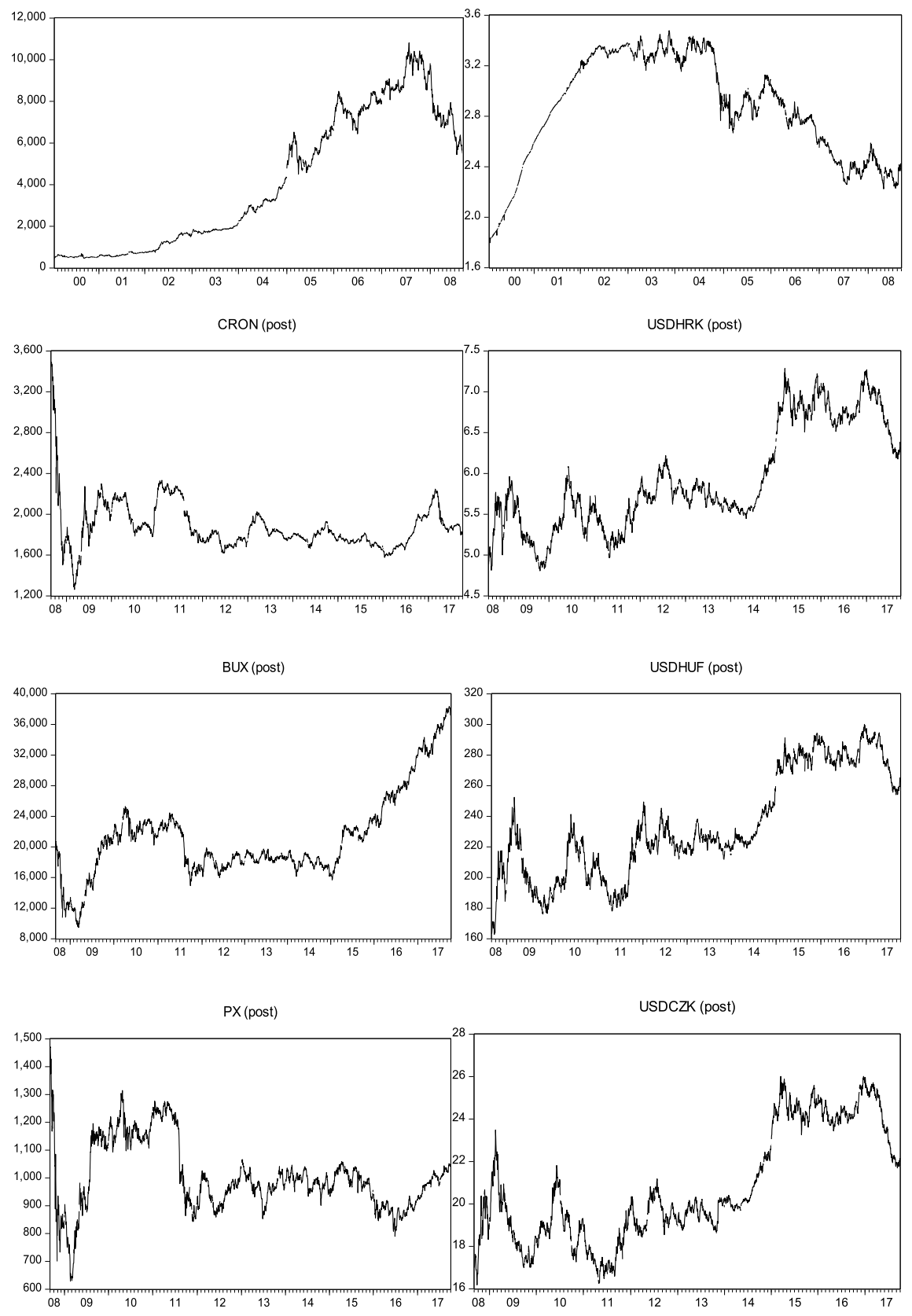

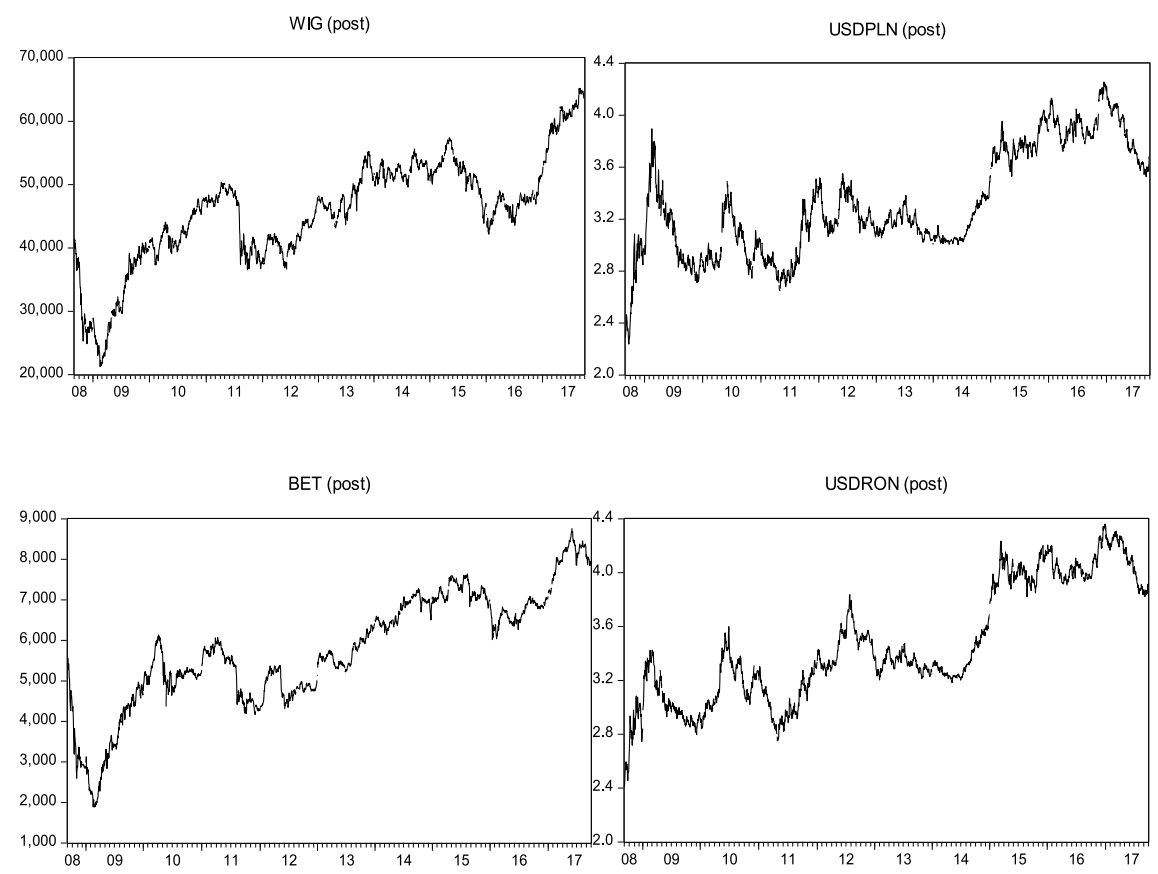

Source: the calculation of the author

\subsection{Model Specification}

\section{Unit root test}

The stationary of the series is considered by commonly checking through (Phillips-Perron PP, 1988) and (Dickey-Fuller ADF, 1979) methods to ensure that the results of the analysis are not spurious. These tests have been implemented to confirm that the data were stationary at level.

\section{EGARCH model}

The empirical study for examining whether the volatility of stock returns affects and is affected by the volatility of exchange rate returns is aimed to be captured by employing Exponential Generalized Autoregressive Conditional Heteroskedasticity (EGARCH) model developed by Nelson (1991). The EGARCH specification is applied to test whether the volatility spillover effects are asymmetric. The simple GARCH model enforces a symmetric effect of volatility (positive shocks) and is not able to capture asymmetric shocks (negative shocks) because of the conditional variance being a function of lagged residuals and not their signs. There is 
no such restriction in EGARCH model on the parameters, the EGARCH model is able to capture both symmetric and asymmetric shocks. Therefore, numerous empirical studies based on the EGARCH framework to specify volatility spillovers between different financial assets in different countries. For instance, except for foregoing mentioned scholars, (Mishra et al., 2007; Choi et al., 2010; Adiasi et al., 2008; Qayyum-Kamal, 2006; Okpara-Odionye, 2012; Beer-Hebein, 2011). In this study, we applied EGARCH(1,1) model to examine the transmission mechanism of volatility separately for each selected country.

EGARCH model for volatility spillover from foreign exchange market to stock market:

$$
\begin{aligned}
& R_{t}=\alpha_{0}+\alpha_{1} R_{t-1}+\alpha_{2} R_{t-1(E R)}+\varepsilon_{t} \\
& h_{t(S P)}=\beta_{0}+\beta_{1} h_{t-1}+\beta_{2}\left|\frac{\varepsilon_{t}-1}{\sqrt{h_{t-1}}}\right|+\phi \frac{\varepsilon_{t}-1}{\sqrt{h_{t-1}}}+\delta_{(\operatorname{resid}(E R))}
\end{aligned}
$$

The equation (1) and (2) represent the $\operatorname{EGARCH}(1,1)$, which is applied for examining volatility spillover from foreign exchange market to stock market in each country.

EGARCH model for volatility spillover from stock market to foreign exchange market:

$$
\begin{aligned}
& K_{t}=a_{0}+a_{1} K_{t-1}+a_{2} K_{t-1(S P)}+\varepsilon_{t} \\
& h_{t(E R)}=\gamma_{0}+\gamma_{1} h_{t-1}+\gamma_{2}\left|\frac{\varepsilon_{t}-1}{\sqrt{h_{t-1}}}\right|+\varphi \frac{\varepsilon_{t}-1}{\sqrt{h_{t-1}}}+\psi_{(\operatorname{resid}(S P))}
\end{aligned}
$$


Table 3

Description of Parameters Equations (1)-(4)

\begin{tabular}{lcc}
\hline Explanation & $\mathbf{S}$ & $\mathbf{E}$ \\
\hline The conditional mean equation & $(1)$ & $(3)$ \\
The conditional variance equation & $(2)$ & $(4)$ \\
Return & $R_{t}$ & $K_{t}$ \\
Intercept & $\alpha_{0}$ & $a_{0}$ \\
Measuring the effects of previous day's return on today's return & $\alpha_{1}$ & $a_{1}$ \\
Measuring the effects of exchange rates changes on stock returns & $\alpha_{2}$ & \\
Measuring the effects of stock returns on exchange rate returns & & $a_{2}$ \\
Error term & $\varepsilon_{t}$ & $\varepsilon_{t}$ \\
Log of conditional variance & $h_{t(S P)}$ & $h_{t((E R)}$ \\
Volatility constant & $\beta_{0}$ & $\gamma_{0}$ \\
Function of volatility (consistency) & $\beta_{1}$ & $\gamma_{1}$ \\
Volatility reaction to change in news & $\beta_{2}$ & $\gamma_{2}$ \\
Measuring asymmetric effect of volatility & $\phi$ & $\varphi$ \\
Volatility spillover & $\delta$ & $\Psi$ \\
\hline
\end{tabular}

Note: $S$ - stock return, $E$ - exchange rate return

The procedure for measuring volatility spillover of this study is implemented in the following stages. An initial step we provide descriptive statistics for stock and exchange rate returns to summarize the statistical characteristics of our sample. We then carry out the stationary test including ADF and PP test on each of the concerned variables. Next step, identifying and estimating an autoregressive and moving average (ARMA) model for the mean equation, using the residuals of the mean equation to test for ARCH effect (the significant value of chi-square depicts $\mathrm{ARCH}$ effect in the underlying variable). EGARCH model shall be employed on data in which ARCH effect exists. After making sure that there exists ARCH effect, we have specified and estimated the volatility spillover between stock market and foreign exchange rate market. Finally, residual diagnostics, ARCH-LM test have been performed. 


\section{RESULTS}

Descriptive statistics for stock and foreign exchange returns as well as unit root are reported in Chart 1-2. The analyses reveal that sample means of stock return are positive and significantly different from zero for five countries except for the Czech Republic and Croatia in the post-crisis period. The sample variances range from $0.69 \%$ for Croatia to $1.62 \%$. for Hungary. Similarly, Hungarian and Polish exchange markets have the highest daily average return over the study period. Skewness and Kurtosis coefficients indicate that return series are far from the normal distribution, this is formally confirmed by The Jarque-Bera test statistics. Finally, all exchange rate changes and stock returns series are found to be stationary at level (e.i I(o)) at the $1 \%$ significance level according to the PP \& ADF statistics.

Chart 4 represents the results of the purpose of $\mathrm{ARCH}$ effect for the underlying variables (stock prices and exchange rate) over the study periods. The ARCH effect illustrates the presence of autocorrelation and heteroskedasticity issues in data. The result shows that there is the strong evidence of the existence of ARCH effect in all concerned series. $\operatorname{EGARCH}(1,1)$ can be employed on data having ARCH effect in data.

Examining volatility spillover between stock and exchange market by using EGARCH(1,1) model is the final step. We have studied on each market information spillover separately for each country. First, we have conducted analyses by examining volatility spillover from the foreign exchange market to the stock market, after that we have continued to examine volatility spillover from the stock market to the exchange market. For selecting the appropriate lag length of each model, the basis of Akaike's information criterion has been selected. 
Table 4

ARCH test

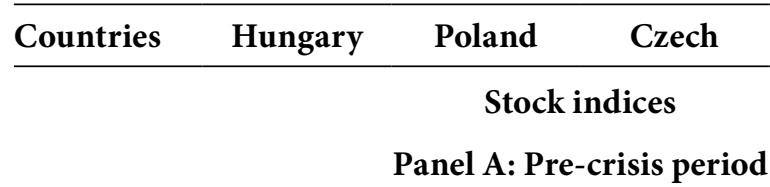

$\begin{array}{llllll}\text { Constant } & 1.254^{*} & 1.021^{*} & 0.892^{*} & 1.525^{*} & 1.137^{*} \\ \text { AR(1) } & 0.061^{*} & 0.042^{* *} & 0.071^{*} & 0.390^{*} & 0.271^{*} \\ \text { ARCH test } & 80.09^{*} & 110.57^{*} & 141.74^{*} & 362.65^{*} & 240.30^{*}\end{array}$

Panel B: Post-crisis period

\begin{tabular}{lccccc} 
Constant & $1.137^{*}$ & $0.579^{*}$ & $0.659^{*}$ & $0.942^{*}$ & $0.544^{*}$ \\
AR(1) & $0.290^{*}$ & 0.020 & $0.228^{*}$ & $0.306^{*}$ & $0.297^{*}$ \\
ARCH test & $363.55^{*}$ & $309.09^{*}$ & $559.10^{*}$ & $411.67^{*}$ & 550.14 \\
& \multicolumn{5}{c}{ Exchange rates } \\
\multicolumn{5}{c}{ Panel A: Pre-crisis period } \\
Constant & $0.515^{*}$ & $0.331^{*}$ & $0.402^{*}$ & $0.2085^{*}$ & $0.335^{*}$ \\
AR(1) & $0.097^{*}$ & $0.137^{*}$ & 0.012 & $0.567^{*}$ & $0.108^{*}$ \\
ARCH test & $25.01^{*}$ & $72.17^{*}$ & $21.37^{*}$ & $576.77^{*}$ & $59.96^{*}$
\end{tabular}

\section{Panel B: Post-crisis period}

$\begin{array}{llllll}\text { Constant } & 0.498^{*} & 0.408^{*} & 0.291^{*} & 0.256^{*} & 0.276^{*} \\ \text { AR(1) } & 0.042^{* *} & 0.158^{*} & 0.084^{*} & 0.038 & 0.173^{*} \\ \text { ARCH test } & 251.82^{*} & 403.89^{*} & 325.83^{*} & 291.60^{*} & 151.88^{*}\end{array}$

Note: ARCH test is the arch effect test.

${ }^{* *}$ denotes the level of significance at $5 \%,{ }^{*}$ indicates $p<1 \%$

Source: the calculation of the author

Chart 5 presents the EGARCH estimations for both the mean and conditional variance equations. The mean equation results show that the changes in the exchange rate have a significant negative impact on stock returns of Hungry, Poland over the study period and the Czech Republic, Romania, Croatia in the post-crisis period, nevertheless, insignificant for the Czech Republic, Romania and Croatia in the pre-crisis period. The significant negative impact of foreign exchange market on stock market reveals that changes in exchange market could reduce stock returns of these countries, this decreases the profitability and stock prices of the 
firms. The negative effect of exchange market would create fluctuation in trade balance and the competitiveness of the country. As a result, it would decrease real income and economic growth (Jebran-Iqbal, 2016). The results of the negative impact of the foreign exchange rate market on the stock return are similar to those of Aloui (2007), Yang-Doong (2011) and Jebran-Iqbal (2016). The findings support the theoretical prediction of stock-oriented models in which reported that there is a negative relationship between foreign exchange rate and stock price. In case of the Czech Republic, Romania and Croatia, there is an insignificant effect of exchange rate on stock returns in the pre-crisis period may postulate the effective hedging strategies against the currency risk in these countries. The results of our empirical analysis indicate that there is also an insignificant linkage between stock market changes and foreign exchange rate dynamics for all countries over study period except Romania in the post-crisis period. The mean equation reveals that stock market fluctuations have a significant negative effect on exchange rate returns in Romania recent years, it supports the theoretical prediction of portfolio balance model which points that exchange rates respond to the demand for and supply of stock market. Consequently, an increase in domestic stock prices will lead investors to sell foreign assets in the market for the purpose of purchasing domestic assets. This result in line with a study like Jebran-Iqbal (2016). Additionally, as regards to other countries, the weak or no impact of stock prices on exchange rate supports the theoretical prediction of monetary approach which presumes that there is no linkage between exchange rate and stock prices. These results are consistent with Ngo Thai Hung (2017).

Turning to the second moment interdependencies, the variance equation results indicate coefficientwhich measures volatility spillover form exchange market to stock market and indicates whether this spillover is asymmetric, is statistically significant for Hungary, Poland in all the periods, Romania and Croatia in the pre-crisis period. For the pre-crisis period, the coefficient is positive in case of Hungary, Poland and Romania, while negative in case of Croatia. For the postcrisis period, the coefficient is positive for Hungary and Poland. The positive coefficient illustrates that foreign exchange market volatility is increasing the volatility of the stock market, on the other hand, negative coefficient shows that foreign exchange market volatility is decreasing the volatility of the stock market. In case of Hungary, Poland and the Czech Republic, the findings are consistent with Morales (2008), Aloui (2007) and Valls-Chuliá (2014).

The measures volatility spillover from stock prices to exchange rates. The coefficient is statistically significant for Hungary and the Czech Republic in all periods, however, insignificant in case of Poland and Romania in the pre-crisis period and Croatia in the post-crisis period. The coefficient is negative in all cases. This negative coefficient describes that stock market volatility is decreasing the volatility of 
foreign exchange market. It is important to note that we find no volatility spillover from exchange market to stock market in case of Czech Republic in both periods and Romania and Croatia in the post-crisis period, and no volatility spillover from the stock market to the exchange market in case of Poland and Romania in the pre-crisis period and Croatia the post-crisis period. These results are in line with Fedorava-Saleem (2010) and inconsistent with Morales (2008).

Briefly, the results are mixed when we compare the volatility spillover with different countries and during two periods because changes in volatility spillover between stock returns and foreign exchange market have changed over time, in particular, have increased in post-crisis period, it is consistent with the notion that financial market integration has increased after crisis period. The results show that there is a bidirectional volatility spillover between stock and foreign exchange market in Hungary in all period and Poland in the post-crisis period that represents the information inefficiency of these stock markets, while unidirectional volatility spillover in Croatia in pre-crisis period and from the stock market to the exchange market in the Czech Republic during two periods. However, no volatility spillover for Croatia in the post-crisis period, this implies that effective strategies against the stock market and exchange rate fluctuations. The absence of volatility spillover from exchange market to stock market in case of the Czech Republic (two periods), Romania and Croatia (post-crisis period) could indicate the effective hedging strategies against currency risk. Finally, the asymmetric spillovers from stock returns to exchange rates have all the positive signs, they are interpreted as follows: good news has a greater impact on volatility than unexpected bad news. On the other hand, the asymmetric spillovers from exchange rates to stock returns have all the negative signs implies that negative shocks generate more volatility than positive shocks of the same magnitude.

In order to evaluate the robustness of the estimation results, we examined the $\mathrm{ARCH}$ effect on the residuals of each model to determine whether the ARCH effect still exists in model. The null hypothesis is that there is ARCH effect. It can be seen in Chart 5 , the results of ARCH test illustrate that we find strong evidence that there is no ARCH effect for all series considered except only for Romania when we estimate the volatility spillover from the stock market to the foreign exchange market in the pre-crisis period. It is similar to the study of (Melik Kamisly et al., 2015) and also a limitation of this investigation. Hence, modeling the EGARCH model can successfully capture the price volatility interaction between stock and exchange markets. 
Table 5

Volatility spillover between stock and foreign exchange market

\begin{tabular}{llllll}
\hline Countries & Hungary & Poland & Czech & Romania & Croatia \\
\hline
\end{tabular}

Volatility spillover from foreign exchange market to stock market

Panel A: Pre-crisis period

$\begin{array}{lccccc}\alpha_{0} & 0.041 & 0.053^{* *} & 0.074^{*} & 0.075^{*} & 0.099^{*} \\ \alpha_{1} & 0.033 & 0.061^{*} & 0.049^{* *} & 0.143^{*} & 0.037 \\ \alpha_{2} & -0.083^{* *} & -0.116^{*} & -0.022 & 0.021 & -0.014 \\ \beta_{0} & -0.082^{*} & -0.080^{*} & -0.133^{*} & -0.221^{*} & -0.167^{*} \\ \beta_{1} & 0.943^{*} & 0.979^{*} & 0.939^{*} & 0.916^{*} & 0.924^{*} \\ \beta_{2} & 0.147^{*} & 0.112^{*} & 0.192^{*} & 0.406^{*} & 0.285^{*} \\ \phi & -0.052^{*} & -0.028^{*} & -0.095^{*} & -0.033^{*} & -0.008 \\ \delta & 0.055^{*} & 0.014^{*} & -0.0006 & 0.134^{*} & -0.092^{*} \\ \text { ARCH LM(1) } & 0.019(0.89) & 3.21(0.07) & 4.48(0.03) & 0.39(0.53) & 2.14(0.14)\end{array}$

Panel B: Post-crisis period

\begin{tabular}{lccccc}
$\alpha_{0}$ & 0.031 & 0.033 & 0.005 & 0.027 & 0.015 \\
$\alpha_{1}$ & -0.016 & $0.052^{* *}$ & 0.024 & $0.067^{*}$ & $0.055^{*}$ \\
$\alpha_{2}$ & $-0.11^{*}$ & $-0.102^{*}$ & $-0.111^{*}$ & $-0.049^{* *}$ & $-0.066^{*}$ \\
$\beta_{0}$ & $-0.110^{*}$ & $-0.094^{*}$ & $-0.159^{*}$ & $-0.285^{*}$ & $-0.156^{*}$ \\
$\beta_{1}$ & $0.986^{*}$ & $0.986^{*}$ & $0.980^{*}$ & $0.957^{*}$ & $0.987^{*}$ \\
$\beta_{2}$ & $0.152^{*}$ & $0.123^{*}$ & $0.209^{*}$ & $0.393^{*}$ & $0.200^{*}$ \\
$\phi$ & $-0.063^{*}$ & $-0.045^{*}$ & $-0.067^{*}$ & $-0.062^{*}$ & $-0.036^{*}$ \\
$\delta$ & $0.016^{* *}$ & $0.027^{*}$ & 0.004 & 0.011 & -0.001 \\
ARCH LM(1) & $0.63(0.42)$ & $0.76(0.37)$ & $0.61(0.43)$ & $2.38(0.12)$ & $0.06(0.79)$ \\
\hline
\end{tabular}




\section{\begin{tabular}{llllll}
\hline Countries Hungary & Poland & Czech & Romania & Croatia \\
\hline
\end{tabular}}

Volatility spillover from the stock market to foreign exchange market

Panel A: Pre-crisis period

$\begin{array}{lccccc}a_{0} & -0.017 & -0.033^{* *} & -0.031^{* *} & 0.078^{*} & -0.036^{*} \\ a_{1} & 0.010 & 0.072^{*} & -0.013 & 0.0004 & -0.072^{*} \\ a_{2} & -0.018 & -0.004 & -0.016 & -0.002 & 0.0002 \\ \gamma_{0} & -0.130^{*} & -0.216^{*} & -1.025^{* *} & -0.100^{*} & -0.057^{*} \\ \gamma_{1} & 0.864^{*} & 0.901^{*} & -0.367^{* *} & 0.993^{*} & 0.995^{*} \\ \gamma_{2} & 0.080^{*} & 0.181^{*} & 0.073^{* *} & 0.123^{*} & 0.069^{*} \\ \varphi & 0.078^{*} & 0.074^{*} & 0.073^{*} & -0.038^{*} & -0.001 \\ \Psi & -0.046^{*} & -0.010 & -0.051^{* *} & -0.004 & -0.015^{*}\end{array}$

ARCH LM(1) $\quad 0.48(0.48) \quad 0.60(0.43) \quad 0.01(0.90) \quad 80.7(0.00) \quad 0.02(0.86)$

Panel B: Post-crisis period

$\begin{array}{lccccc}a_{0} & 0.011 & 0.016 & 0.017 & 0.011 & 0.014 \\ a_{1} & -0.026 & -0.04^{* *} & -0.005 & -0.008 & -0.032 \\ a_{2} & -0.001 & -0.025 & 0.015 & -0.023^{* *} & -0.018 \\ \gamma_{0} & -0.046^{*} & -0.062 & -0.077^{*} & -0.050^{*} & -0.047 \\ \gamma_{1} & 0.996^{*} & 0.994^{*} & 0.992^{*} & 0.993^{*} & 0.996^{*} \\ \gamma_{2} & 0.058^{*} & 0.078^{*} & 0.091^{*} & 0.057^{*} & 0.047^{*} \\ \varphi & 0.025^{*} & 0.028^{*} & 0.019^{*} & 0.0211^{*} & 0.029^{*} \\ \Psi & -0.016^{*} & -0.022^{*} & -0.021^{*} & -0.012^{*} & -0.007\end{array}$
ARCH LM(1)
$0.08(0.76)$
$1.25(0.26)$
$0.34(0.55)$
$0.14(0.70)$
$4.49(0.03)$

Note: ${ }^{*}$ denotes the level of significance at $5 \%,{ }^{*}$ indicates $p<1 \%$. Numbers in parentheses are probability.

Source: the calculation of the author 


\section{CONCLUSION}

In this study, we have investigated the empirical dynamics of volatility spillover effects between the stock market and foreign exchange market in Central and Eastern European countries i.e. Hungary, Poland, the Czech Republic, Romania and Croatia across the pre-crisis and post-crisis periods using EGARCH model.

Our empirical evidence shows that there is a bidirectional volatility spillover between stock and foreign exchange markets in Hungary in all periods and Poland in the post-crisis period. The results also reveal unidirectional volatility spillover in Croatia in the pre-crisis period and from the stock market to the exchange market in the Czech Republic during two periods. In the post-crisis period, the two financial markets show the non-presence of the volatility spillover between them in Croatia. The spillovers are asymmetric in nature in all financial markets. Volatility spillover from stock returns to exchange rates have decreased after the crisis period. The volatility persistence indicates that there was volatility persistence in all series in all periods, in general, the persistence of exchange market volatility was found greater than stock market volatility.

Our findings have several important economic and finance implications for economic policymakers and investors. First, international portfolio managers and hedgers may be better able to understand how the two financial markets interrelated overtime, they might provide them benefit in forecasting the behavior of one market by capturing the other market information. Second, the information concerning the nature of volatility transmission across stock and exchange markets in the country would be important for policymakers and decision makers from an economic stability perspective as financial markets integration through exchange rates imply financial sector integration. Third, for investors, this should be particularly important when they want to make an efficient portfolio, can apply these results in reducing their risk, increase their returns and make decisions in the selected markets. 


\section{REFERENCES}

Agrawal, G. - Srivastav, A. K. - Srivastava, A. (2010): A Study of Exchange Rates Movement and Stock Market Volatility. International Journal of Business and Management 5(12), 62-73, https:// doi.org/10.5539/ijbm.v5n12p62.

Aloui, C. (2007): Price and Volatility Spillovers Between Exchange Rates and Stock indexes for the pre/ and post-Euro period. Quantitative Finance, No. 6, 669-685, https://doi. org/10.1080/14697680701302653.

BARUník, J. - KočEndA, E. -VÁcha, L. (2016): Asymmetric connectedness on the US stock market: Bad and good volatility spillovers. Journal of Financial Markets 27, 55-78, https://doi. org/10.1016/j.finmar.2015.09.003.

Beer. F. - Hebein, F. (2011): An Assessment of The Stock Market and Exchange Rate Dynamics in Industrialized and Emerging Markets. International Business Economic Research Journal 7(8), 59-70, https://doi.org/10.19030/iber.v7i8.3283.

Choi, D. F. S. - FAng, V. - Fu, T. Y. (2010): Volatility Spillovers Between New Zealand Stock Market Returns and Exchange Rate Changes Before and After the 1997. Asian Financial Crisis. Asian Journal of Finance \& Accounting 1(2), 106-117, https://doi.org/10.5296/ajfa.v1i2.140.

Dickey, D. - Fuller, W. (1979): Distribution of the estimators for autoregressive time series with a unit root. Journal of the American Statistical Association 74(366a), 427-431, https://doi. org/10.2307/2286348; https://doi.org/10.1080/01621459.1979.10482531.

Diebold, F. X. - Yilmaz, K. (2009): Measuring financial asset return and volatility spillovers, with application to global equity markets. The Economic Journal, 119(534), 158-171, https://doi. org/10.1111/j.1468-0297.2008.02208.x.

Diebold, F. X. - Yilmaz, K. (2012): Better to give than to receive: Predictive directional measurement of volatility spillovers. International Journal of Forecasting, 28(1), 57-66, https://doi. org/10.1016/j.ijforecast.2011.02.006.

Diebold, F. X. - Yilmaz, K. (2014): On the network topology of variance decompositions: Measuring the connectedness of financial firms. Journal of Econometrics 182(1), 119-134, https://doi. org/10.1016/j.jeconom.2014.04.012.

Dornbusch, R. -Fischer, S. (1980): Exchange Rates and The Current Account. American Economic Review 70(5), 960-971.

Fedorova, E. J. - Saleem, K. (2009): Volatility Spillovers Between Stock and Currency Markets: Evidence from Emerging Eastern Europe. Czech Journal of Economics and Finance 60(6), 519-533, https://doi.org/10.2139/ssrn.1460645.

Frankel, J. A. (1983): Monetary and Portfolio - Balance Models of Exchange Rate Determination. In: Bhandari, J. S. - Putnam, B. H. (eds.): Economic Interdependence and Flexible Exchange Rates. Cambridge: MIT Press..

Jerban, K. - IqBAL, A. (2016): Dynamics of Volatility Spillover Between Stock Market and Exchange Market: Evidence from Asian Countries. Financial Innovation 2(3), 1-20, https://doi.org/10.1186/ S40854-016-0021-1.

KamişLi, M. - KamişLi, S. - Özer, M. (2015): Are Volatility Transmissions Between Stock Market Returns of Central and Eastern European Countries constant or dynamic? Evidence from MGARCH Models. In the conference proceedings of 1oth MIBES Conference, 15-17 October 2015, Larisa (Greece), 190-203.

Kanas, A. (200o): Volatility Spillovers Between Stock Return and Exchange Rate Changes: International Evidence. Journal of Business Finance and Accounting 27(3), 447-467, https://doi. org/10.1111/1468-5957.00320. 
Mishra, A. K. - Swain, N. - Malhotra, D. K. (2007): Volatility Spillover Between Stock and Foreign Exchange Markets: Indian Evidence. International Journal of Business 12(3), 343-359.

Morales, L. (2008): Volatility Spillovers Between Stock Returns and Foreign Exchange Rates: Evidence from Four Eastern European Countries. In the conference proceedings of the Financial Management Association (FMA) European Conference, 4-6 June 2008, Prague (Czech Republic).

Mozumder, N. - De Vita, G. - Kyaw, K. - Larkin, C. (2015): Volatility Spillover Between Stock Prices and Exchange Rates: New Evidence Across the Recent Financial Crisis Period. Economic Issues $20(1), 43-64$.

Nelson, D. B. (1991): Conditional Heteroskedasticity in Asset Returns: A New Approach. Econometrica 59(2), 347-370, https://doi.org/10.2307/2938260.

Ngo Thai Hung (2017): An Empirical Test on Linkage between Foreign Exchange Market and Stock Market: Evidence from Hungary, Czech Republic, Poland And Romania. European Scientific Journal 13(31), 25-38, https://doi.org/10.19044/esj.2017.v13n31p25.

Okpara, G. C. - Odionye, J. C. (2012): The Direction of Volatility Spillover between Stock Prices and Exchange Rate: Evidence From Nigeria. Elixir Finance 42, 6410-6414.

Phillips, P. - Perron, P. (1988): Testing for a unit root in time series regression. Biometrika 75(2), 335-346, https://doi.org/10.1093/biomet/75.2.335.

Qayyum, A. - Kamal, A. R. (2006): Volatility Spillover Between the Stock Market and the Foreign Market in Pakistan. Pakistan Institute of Development Economics Working Papers 7, https://doi. org/10.2139/ssrn.963308.

Segal, G. - Shaliastovich, I. - Yaron, A. (2015): Good and bad uncertainty: Macroeconomic and financial market implications. Journal of Financial Economics, 117(2), 369-397, https://doi. org/10.1016/j.jfineco.2015.05.004.

Valls, N. - Chulí́, H. (2014): Volatility Transmission Between the Stock and Currency Markets in Emerging Asia: The Impact of the Global Financial Crisis. Research Institute of Applied Economics $31,1-26$.

YANG, S-Y. - Doong, S-C.: (2004): Price and Volatility Spillovers Between Stock Prices and Exchange Rates: Empirical Evidence from the $\mathrm{G}-7$ Countries. International Journal of Business and Economics 3(2), 139-153. 